\title{
Etiology of Farcy in African Bovines: Nomenclature of the Causal Organisms Mycobacterium farcinogenes Chamoiseau and Mycobacterium senegalense (Chamoiseau) comb. nov.
}

\author{
G. CHAMOISEAU \\ Centre National d'Elevage et de Recherches Vétérinaires, B. P. 167, Nouakchott, Mauritanie
}

\begin{abstract}
In 1973 the author proposed the name Mycobacterium farcinogenes for the causal agent of farcy in African bovines. Two varieties (subspecies) of this species were recognized by the author: $M$. farcinogenes subsp. tchadense and $M$. farcinogenes subsp. senegalense. Because the former is the type subspecies of the species, its name should have been $\boldsymbol{M}$. farcinogenes subsp. farcinogenes. It is now proposed that these subspecies constitute two separate and distinct species: $\boldsymbol{M}$. farcinogenes Chamoiseau and $M$. senegalense (Chamoiseau) comb. nov. IEMVT $75(=$ NCTC 10955) and IEMVT $378(=$ NCTC 10956) are herein designated the type strains of these two species, respectively.
\end{abstract}

Since 1970 it has been known both in Chad and in Senegal that farcy, the disease of African bovines, is really a mycobacteriosis and that in most cases it is not due to Nocardia farcinica, as had been believed for a long time.

The work of Asselineau et al. (1) and of Laneelle et al. (6) on the lipid components of the farcy actinomycete isolated from zebu cattle in Chad and Senegal has recently been confirmed by Sudanese investigators (5), who studied the farcy actinomycete isolated from bovines in the Sudan.

These studies indicate that the etiological agent of farcy in African bovines is a mycobacterium, not a nocardia. The organisms isolated from the lesions of bovine farcy in Chad, Senegal, and the Sudan indeed exhibit the acidfastness, cultural characteristics, and lipid composition characteristic of Mycobacterium.

Since 1973, it has been apparent that the culture isolated from bovine sources in Chad differ in certain respects from those isolated in Senegal, as follows (4). (i) Cultural characteristics: Chad strains grow slowly and Senegal strains grow rapidly (2). (ii) Biochemical properties: Senegal strains exhibit broader and more intense amidase and glucolytic activities than do Chad strains $(2,3)$. (iii) Lipid composition: Senegal strains contain the rarely encountered mycoside $C^{\prime}(6)$. (iv) Pathogenicity for experimental animals: Senegal strains produce a massive, generalized peritonitis in guinea pigs; Chad strains cause a peritonitis with large but limited individual abscesses (4).

It was the above-mentioned differences that led to the separation of the Chad and the Senegal strains into two varieties (subspecies) of the same species, both responsible for anatomically and pathologically identical clinical syndrome of bovine farcy, by me in 1973 (4). At this time, I proposed the names Mycobacterium farcinogenes subsp. tchadense and $M$. farcinogenes subsp. senegalense for these organisms. It has subsequently been determined that the name of the type subspecies, $M$. farcinogenes subsp. tchadense, should have been $M$. farcinogenes subsp. farcinogenes (7). Although type strains were not designated for these taxa, cultures of representative strains were deposited in the $\mathrm{Na}$ tional Collection of Type Cultures (NCTC) in London; the Chad strain (IEMVT 75) was given the NCTC number 10955, and the Senegal strain (IEMVT 378), the number 10956.

Furthermore, it is now known that the Chad strains also differ from the Senegal strains because of the low degree of homology between their deoxyribonucleic acid bases. Indeed, Baess (personal communication) determined the percent relatedness of the deoxyribonucleic acid of $M$. farcinogenes subsp. tchadense IEMVT 93B and that of $M$. farcinogenes subsp. senegalense IEMVT 378 to be $48 \pm 2.6$ standard deviation; this value indicates that these organisms belong to different species. The name of the species that includes the Chad strains is Mycobacterium farcinogenes Chamoiseau 1973 (syn.: $M$. farcinogenes subsp. tchadense Chamoiseau); the name of the species that includes the Senegal strains is Mycobacterium senegalense (Chamoiseau) comb. nov. (7). The type strain of these species are herein designated as IEMVT 75 (= NCTC 10955) and IEMVT 378 (= NCTC 10956), respectively.

The characters of the type strains are given in 
TABLE 1. Characteristics of the strains of $M$. farcinogenes and $M$. senegalense

Characteristic ceral parenchyma of cattle with the disease farcy

Strains originally isolated in:

West Africa (Senegal)

Central Africa (Chad)

East Africa (Sudan)

M. farcinogenes

M. senegalense

Morphology of cells

In pus from lesions: short or long filaments, bent and branched, assembled in clumps or tangled, lacey network

No fragmentation into bacillary forms

Staining properties Coloration by Gram stain

Acid-alcohol resistant by Ziehl-Neelsen stain

Morphology in smears from culture: same characteristics as above

Cultural characteristics

Coletsos or Löwenstein-Jensen medium:

$+$

$+$

(1)

$+$

$+$

$\begin{array}{ll}+ & + \\ + & + \\ + & + \\ + & +\end{array}$

15 to 20 days

$+$

Honey yellow Impossible

15 to 20 days
+

$+$

20 to 30 days

Very thin

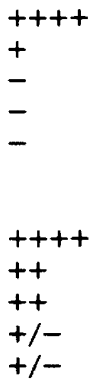

$-$

$-$

$+$

$-$

$\begin{array}{ll}- & + \\ - & - \\ - & \pm \text { or }-\end{array}$

$+$

Ochre

$+$

$+$

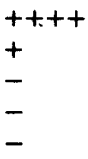

++++
++++
++++
++++
+

$++$

$++$

$+$

$+$
Time for growth

Rough, convoluted colonies firmly attached to medium, surrounded by iridescent halo

Pigment

Emulsion in distilled water

Tryptose broth with serum:

Time for growth

Thick, rough, dry, whitish surface veil

Broth remains clear

Sauton medium (plain or with serum):

Time for growth

Dry, whitish surface veil

Cytochemical reactions

Catalase

Nitrate reductase

Niacin production

Iron citrate test

Neutral red test

Amidase activity

Acetamidase and formamidase

Allantoinase

Benzamidase, nicotinamidase, and isonicotinamidase

Urease

Salicylamidase

24 to $48 \mathrm{~h}$

Relatively easy

24 to $48 \mathrm{~h}$

24 to $48 \mathrm{~h}$

Fairly abundant

Pyruvate, citrate, benzoate

Malonate

Proteolytic activity

Urea

Gelatin

Casein, tyrosine, hypoxanthine, xanthine 
TABLE 1.-Continued

\begin{tabular}{|c|c|c|}
\hline Characteristic & M. farcinogenes & M. senegalense \\
\hline \multicolumn{3}{|l|}{ Antibiotic susceptibilities } \\
\hline Isoniazid & Resistant & Resistant \\
\hline$p$-Aminosalicylic acid & Resistant & Resistant \\
\hline Ethionamide & Resistant & $\begin{array}{l}\text { Limited susceptibil- } \\
\text { ity }\end{array}$ \\
\hline Viomycin & Susceptible & Susceptible \\
\hline Cycloserine & Susceptible & Susceptible \\
\hline Streptomycin & Resistant & $\begin{array}{l}\text { Limited susceptibil- } \\
\text { ity }\end{array}$ \\
\hline Kanamycin & Susceptible & Susceptible \\
\hline \multicolumn{3}{|l|}{ Lipid composition } \\
\hline Abundance of chloroform-soluble fraction & + & + \\
\hline Presence of normal fatty acids with $>20 \mathrm{C}$ atoms & + & + \\
\hline $\begin{array}{l}\text { Presence of } \beta \text {-hydroxy mycolic acids, which yield tetra- } \\
\text { cosanoic acid on pyrolysis }\end{array}$ & + & + \\
\hline Cord factor in chloroform extract & + & + \\
\hline Hexacosanoic acid present & - & - \\
\hline Nocardomycolic acid present & - & - \\
\hline Mycoside $\mathrm{C}^{\prime}$ present & - & + \\
\hline \multicolumn{3}{|l|}{ Pathogenicity to guinea pigs } \\
\hline \multicolumn{3}{|l|}{ Subcutaneous injection } \\
\hline Time period & 8 days & 2 days \\
\hline Draining abscess healing slowly & + & + \\
\hline \multicolumn{3}{|l|}{ Intraperitoneal injection } \\
\hline Time period & 6 to 7 days & 3 to 4 days \\
\hline $\begin{array}{l}\text { Abscesses observed in testes, seminal vesicles, or } \\
\text { vagina }\end{array}$ & + & + \\
\hline Abscesses in peritoneal walls and viscera & $\begin{array}{l}\text { Large, localized, } \\
\text { rare }\end{array}$ & $\begin{array}{l}\text { Very numerous mil- } \\
\text { iary }\end{array}$ \\
\hline Susceptibility to tuberculin & + & + \\
\hline Mortality after prolonged infection & + & + \\
\hline Survival & Rare & Rare \\
\hline $\begin{array}{l}\text { Organism recovered from pus has morphology and } \\
\text { staining properties already cited }\end{array}$ & + & + \\
\hline
\end{tabular}

Table 1. The majority of the strains examined by the author to date have characters identical to those reported here for the type strains.

$M$. farcinogenes and $M$. senegalense differ from other known mycobacteria in that they are obtained from lesions of the lymphatic system or the parenchyma of African bovines and present: (i) A very stable mycelium (does not break into bacillary fragments) whether in natural or experimental lesions, in culture, or in smears (2, 4) (ii) A distinctive pathogenicity for the guinea pig, which is very characteristic of these species (4). (iii) A positive malonamidase test, which is rarely encountered with "atypical" mycobacteria (3). (iv) A low deoxyribonucleic acid relatedness with otherwise closely related species; e.g., M. senegalense NCTC 10956 and Mycobacterium fortuitum ATCC 9820 show a percent relatedness of only $46.5 \pm 5$ standard deviations (Baess, personal communication) (v) A new my- coside, $\mathrm{C}^{\prime}$, in $M$. senegalense, which makes this a unique species (6)

\section{ACKNOWLEDGMENTS}

I thank Lawrence G. Wayne, Ernest H. Runyon, E. F. Lessel, and Ellen Nel for clarifying the arcana of the Code; Inga Baess, who permitted me to present her deoxyribonucleic acid hybridization data; and George P. Kubica, who translated the text into English.

\section{REPRINT REQUESTS}

Address reprint requests to: Dr. G. Chamoiseau, CNERV, B.P.:167 Nouakchott, Mauritanie.

\section{LITERATURE CITED}

1. Asselineau, J., M. A. Laneelle, and G. Chamoiseau. 1969. De l'étiologie du farcin de zébus tchadiens: nocardiose ou mycobacteriose? II. composition lipidique. Rev. Elev. Med. Vet. Pays Trop. 22:205-209.

2. Chamoiseau, G. 1969. De l'étiologie du farcin de zébus tchadiens: nocardiose ou mycobactériose? I. Etude bacterrologique et biochimique. Rev. Elev. Med. Vet. Pays Trop. 22:195-204. 
3. Chamoiseau, G. 1972. De l'étiologie du farcin de zébus tchadiens: nocardiose ou mycobactériose? III. Activité amidasique. Rev. Elev. Med. Vet. Paays Trop. 25: 191194.

4. Chamoiseau, G. 1973. Mycobacterium farcinogenes agent causal du farcin du boeuf en Afrique. Ann. Microbiol. Inst. Pasteur 124 A:215-222.

5. El Sanoussi, S. M., M. H. Tageldin, and S. M. Abdel Wahab. 1977. Classification of the bovine farcy organism. Trop. Anim. Health Prod. 8:124.
6. Laneelle, G., J. Asselineau, and G. Chamoiseau. 1971. Présence de Mycosides $C^{\prime}$ (formes simplifiées de mycoside $\mathrm{C}$ ) dans les bactéries isolées de bovines atteints de farcins. FEBS Lett. 19:109-111.

7. Lapage, S. P., P. H. A. Sneath, E. F. Lessel, V. B. D. Skerman, H. P. R. Seeliger, and W. A. Clark (ed). 1975. International code of nomenclature of bacteria. 1976 revision. American Society for Microbiology. Washington, D.C. 